\title{
Diversity of Epiphytic Lactic Acid Bacteria (LAB) on Insect Oviposition Sites
}

\author{
R. Harshini ${ }^{1}$, P. Yasodha ${ }^{1}$, K.G. Sabarinathan ${ }^{1}$, V. Ambethgar ${ }^{1}$ and P.M.M. David $^{2}$ \\ ${ }^{1}$ Anbil Dharmalingam Agricultural College and Research Institute, \\ Trichy-620009, Tamil Nadu \\ ${ }^{2}$ Agricultural College and Research Institute, Killikulam, \\ Vallanadu - 625 282, Tamil Nadu, India
}

*Corresponding author

A B S T R A C T

\section{Keywords}

Insect oviposition sites, Crop plants, Epiphytic lactic acid bacteria $(\mathrm{LAB})$

Article Info

Accepted:

06 June 2018

Available Online:

10 July 2018
Alternative strategies are needed in pest management to protect crops from pests. Occurrence of epiphytic lactic acid bacteria (LAB) on crop plants, especially on sites that are selected by pests, may be associated with host selection by insects. We carried out laboratory investigations as well as screen house and field experiments to understand whether epiphytic LAB occur at oviposition sites of agricultural and horticultural crops, probably modulating pest abundance by attraction or repulsion. The diversity of such epiphytic LAB associated with insect oviposition sites is discussed.

\section{Introduction}

With pesticides leading to environmental pollution, alternative strategies need to be explored in integrated pest management. Lactic acid bacteria (LAB) such as Carnobacterium, Enterococcus, Lactobacillus, Lactococcus, Leuconostoc, Oenococcus, Pediococcus, Streptococcus, Tetragenococcus, Vagococcus and Weissella (Stiles and Holzapfel, 1997; Makarova et al., 2006) which produce a variety of antimicrobial compounds and other substances, confer a range of health benefits not only in higher animals but also in insects, e.g. honeybee (Vásquez et al., 2012; Mathialagan, 2014). They are generally recognized as safe (GRAS) food grade microorganisms exploited as probiotics (Salminen, 1998) and in biopreservation (Carr et al., 2002; Dalie et al., 2010). They occur not only in food-related habitats such as milk but also in soil, water, manure, sewage, silage and plants (Harzallah and Belhadj, 2013). The potential of epiphytic LAB as biocontrol agents against phytopathogenic bacteria and fungi has earlier been documented (Trias et al., 2008). While bacterial species such as Staphylococcus sp. 
and Bacillus sp. associated with oviposition resources serve to regulate subsequent insect attraction and colonization (Zheng et al., 2013), LAB may also help regulate pest populations on plants. The objective of this investigation was to understand the diversity of epiphytic LAB that occur on sites selected by lepidopteran insects for oviposition so that they can be exploited to modulate pest populations in IPM.

\section{Materials and Methods}

Laboratory, screenhouse and field experiments were conducted at the Department of Agricultural Entomology, Anbil Dharmalingam Agricultural College and Research Institute, Trichy, Tamil Nadu during 2015-16.

\section{Laboratory studies}

Crop samples (ca. 1" long, $1 \mathrm{~cm}$ wide) that serve as probable oviposition sites were collected between 6.00 and 8.00 am. The impression method was adopted to isolate the epiphytic LAB before enumerating their numbers and morphology in the laboratory (temp. $34 \pm 2^{0}$ C, $75 \pm 5 \% \mathrm{RH}, 12 \pm 1 \mathrm{hr}$ photoperiod) (Table 1). The samples were pressed on Lactobacillus MRS Agar (de Mann Rogosa Sharpe) medium (Himedia Laboratories), a specific medium for LAB growth. Cycloheximide $(0.1 \%)$ was added before plating in order to prevent fungal growth and other contamination. Calcium carbonate $\left(\mathrm{CaCo}_{3}\right)$ was added $(0.8 \mathrm{~g} / 100 \mathrm{ml})$ to induce better LAB growth (Wright and Klaenhammer, 1981; Aween, 2012). As the LAB growth differed with the samples, it was observed 12 hours after getting the impression. The colony forming units (CFUs) were counted manually and expressed as CFUs/sample on $1^{\text {st }}$ and $2^{\text {nd }}$ day after plating. Then single colonies from the main cultures were streaked on MRS medium before gram staining for microscopic examination to record the morphology of the culture at $10 \times 100$ oil magnification in an image analyzer (CETI). The cultures thus obtained were preserved in the form of slants for further identification and storage.

\section{Screen house and field experiments}

In a screen house experiment, the response of yellow stem borer Scirpophaga incertulas (Wlk.) was evaluated after spraying an LAB culture isolated from rice leaf, where $S$. incertulas / leaffolder (Cnaphalocrocis medinalis) moths lay eggs, and releasing neonate $S$. incertulas larvae emerging from field collected egg masses. After inoculating the above LAB isolate in MRS broth, the culture was left for seven days to multiply before mixing $50 \mathrm{ml}$ water-based soft insecticidal soap, $50 \mathrm{ml}$ water and $25 \mathrm{ml}$ of the LAB culture. From this stock solution, $3.75 \mathrm{ml}$ was added to $250 \mathrm{ml}$ water as the spray fluid and sprayed using a $250 \mathrm{ml}$ capacity hand atomizer. Spraying was done at weekly interval after assessing insect damage and LAB numbers. The treatments included i) LAB spray and ii) untreated control. A set of five plants in tube pots (15 high x $12 \mathrm{~cm}$ in diameter) served as a treatment. After spraying the LAB culture, 3-5 field collected $S$. incertulas egg masses were placed on the experimental plants in both the treatment cages $(90 \times 60 \mathrm{~cm})$ before counting the dead hearts two weeks later.

Two field experiments in rice, one with TRY 1 and the other with TRY 3 varieties, were also conducted with the above two treatments in eight one-cent plots (4 for each treatment) to understand the influence of LAB on insects after spraying the above LAB culture. Spraying was carried out at fortnightly interval and counts on LAB by leaf impression method and injury due to $S$. incertulas and $C$. medinalis was recorded from 5 to 10 hills / 
plot. The experimental data were subjected to paired t-test analysis with log transformation for LAB counts and angular transformation for insect damage.

\section{Results and Discussion}

\section{Diversity of epiphytic LAB}

The results indicated that the $\mathrm{LAB}$ were present in all the plant samples examined, greatly diversified in their morphological characters (Table 1). Their population ranged from $7.33 \pm 1.45 /$ sample in jasmine flower bud where the budworm, Hendecasis duplifascialis Hmpsn. lays eggs to $271.33 \pm$ 39.50/sample where the diamond-back moth Plutella xylostella (L.) oviposits. Morphologically, the cells were cocci or rods, in singles or doubles, in chains short or long. In the screenhouse experiment, though no significant difference could be observed in LAB population between the treated and untreated control plants $(16.00 \pm 1.0-16.75 \pm$ 2.60 CFU/leaf sample), the dead heart injury due to $S$. incertulas was significantly higher $(\mathrm{P}$ $<0.05)$ in untreated control plants $(8.63 \pm 1.69$ $\%)$ than that in treated plants $(6.79 \pm 1.43 \%)$ after spraying the LAB isolated from rice leaf and introducing $S$. incertulas egg masses (Fig. 1). When the data from both the field experiments were pooled and analysed for both LAB population and injury due to insect pests following treatments with the LAB culture isolated from the leaf site where $S$. incertulas and $C$. medinalis lay eggs, no significant difference in $\mathrm{LAB}$ population density could be observed between the treated and untreated control plots $(32.61 \pm 2.52-$ $42.15 \pm 5.27 \mathrm{CFU} /$ leaf sample) and in white ear $(14.06 \pm 1.80-16.22 \pm 1.90 \%)$ (Table 2). However, $C$. medinalis damage was significantly higher $(\mathrm{P}<0.05)$ in untreated control plots $(16.73 \pm 2.83 \%)$ than that in treated plots $(13.35 \pm 2.47 \%)$. Similarly, the dead heart injury was also significantly higher
$(\mathrm{P}<0.05)$ in untreated control plots $(3.04 \pm$ $0.81 \%)$ than in treated plots $(1.91 \pm 0.57 \%)$. In sustainable agriculture, lactic acid bacteria are exploited as one of the microbes (Mostafiz et al., 2012) as they are commonly found on fresh fruits and vegetables (Trias et al., 2008). In this study too, LAB were isolated from different plant parts that are preferred by insect pests for egg laying. It is probable that these epiphytic LAB are associated with the health of these host plants, nutritionally, or in its defence against pests and diseases, or both. Strains such as Lactobacillus paracasei subsp. tolerans and Lactobacillus paracasei subsp. paracase $i$ have been reported as plant growth promoting bacteria (PGPB) (Murthy et al., 2012). As one of the 'effective microorganisms (EM)' they are antagonistic to plant pathogenic fungi (Higa and Kinjo, 1991). As seed treatment in chilli, Lactobacillus sp. inhibited not only Xanthomonas campestris but also promoted plant growth (Kannan et al., 2014). This study explored whether they can help rice plants protect themselves from selected pests, probably by influencing host selection through the volatiles they produce. For instance, the LAB present on human skin produce volatiles which may attract or repel Anopheles gambiae (Okumu et al., 2010) as the bacterium, Staphylococcus sp. converts branched-chain amino acids to highly odorous short-chain volatile fatty acids (James et al., 2004) that play an important role in the host-seeking behaviour of A. gambiae (Smallegange et al., 2009; Knols et al., 1997). Choi et al., (2016) reported that the volatile odour diacetyl produced by LAB as an oxidized by-product of fermentation in the presence of citrate in rotting citrus fruit, attracted the bacteriovorous nematode, Caenorhabditis elegans, mediated by the diacetyl odour receptor, ODR-10.

Lactic acid bacteria often occur in abundance in cereals and their fermented products. LAB associated with rice include Lactobacillus 
johnsonii (Doi et al., 2013), Lb. plantarum (Olympia et al., 1995), Lactobacillus delbrueckii and Sporolactobacillus inulinus (Fukushima et al., 2004), probably co-evolved over the years similar to those in grapes and sugarcane (Sobrun et al., 2012; Aplevicz et al., 2014). Lactobacillus fermentum, Lb. plantarum and $L b$. paracace $i$ have earlier been reported to develop in the natural fermentation products of rice straw (Gao et al., 2008). Similarly, Pediococcus pentosaceus is the most abundant LAB species in paddy rice silage (Ni et al., 2015). Many bacteria produce cell-surface polysaccharides involved in a wide variety of biological functions including protection from environmental stresses, adherence to surfaces, pathogenesis and symbiosis (Jolly et al., 2002). They are associated with virulence and cell protection against desiccation, osmotic stress, antibiotics, toxic compounds, and bacteriophage or protozoa attack (Sanchez et al., 2006). Exopolysaccharides which are loosely attached or excreted into the environment (Boels et al., 2001), either homopolysaccharides or hetero polysaccharides (De Vuyst and Degeest, 1999), may help the LAB survive on plants. As most $\mathrm{LAB}$ isolated in this study produce exopolysaccharides in the laboratory, these biopolymers may also influence the behaviour of pests and their populations, especially at night when the pests will be more active in the presence of dew coupled with low atmospheric temperature. In addition to the exopolysaccharides, LAB produces several antimicrobial metabolites such as oxygen metabolites (hydrogen peroxide and free radicals) and catabolism end-products (Vandenbergh, 1993; Rattanachaikunsopon and Phumkhachorn, 2010). Many strains of LAB produce specific compounds with antimicrobial activity, called bacteriocins (Piard and Desmazeaud, 1991). Bacteriocins are proteins or protein complexes which have inhibition activity against gram-positive and negative bacteria (Tagg et al., 1976). Since bacteriocins allow the LAB to compete even in non-fermentative ecosystems (Lindgren and Dobrogosz, 1990), they are also likely to produce these compounds on crop surface as well, influencing insect behaviour too. Since $\mathrm{LAB}$ have the ability to break down organic matter, thereby releasing amino acids, sugars, alcohols, hormones and similar organic compounds that are absorbed by plants (Alagukannan and Ashokkumar, 2015), these substances may also help modify insect behaviour.

\section{LAB and oviposition}

Abiotic and biotic environmental factors often influence the production or release of behaviour-modifying chemicals by a plant, and therefore affect oviposition preferences (Renwick, 1989). In black soldier fly, Hermetia illucens (L.) (Diptera: Stratiomyidae), different bacterial species mediate oviposition (Zheng et al., 2013). Gravid house flies Musca domestica L. (Diptera: Muscidae) evaluate volatiles produced by microbes on conspecific eggs to ensure synchronous larval development which allows for aggregative feeding and reduced likelihood of cannibalism (Lam et al., 2007). As most crops have LAB on their surface as documented in this study, they may also serve as a mechanism regulating attraction, colonization and succession of insect species. For example, in sugarcane, three different LAB strains were isolated from the sites where three different borer moths \{Chilo infuscatellus Snell., Chilo sacchariphagus indicus (Kapur) and Scirpophaga excerptalis Wlk.\} lay eggs, all cocci in singles or doubles or short chains $(41.66 \pm 13.12$ to $111.33 \pm$ 39.63 CFU/leaf sample). This shows that the adults may select the right place of egg laying owing to the presence of specific epiphytic LAB even though plant volatiles do attract. 
Table.1 The diversity of epiphytic LAB isolated from different oviposition sites on crops

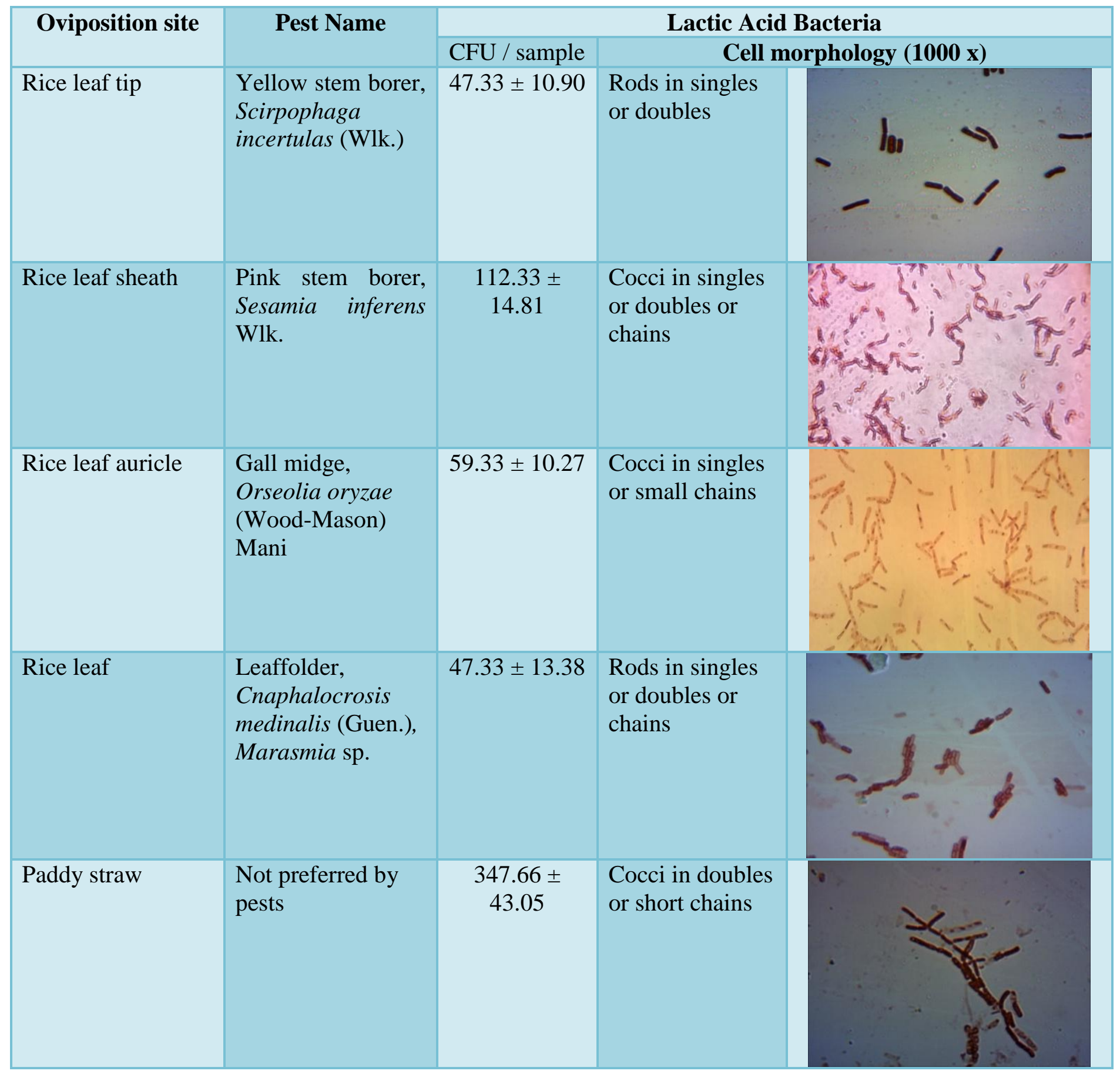




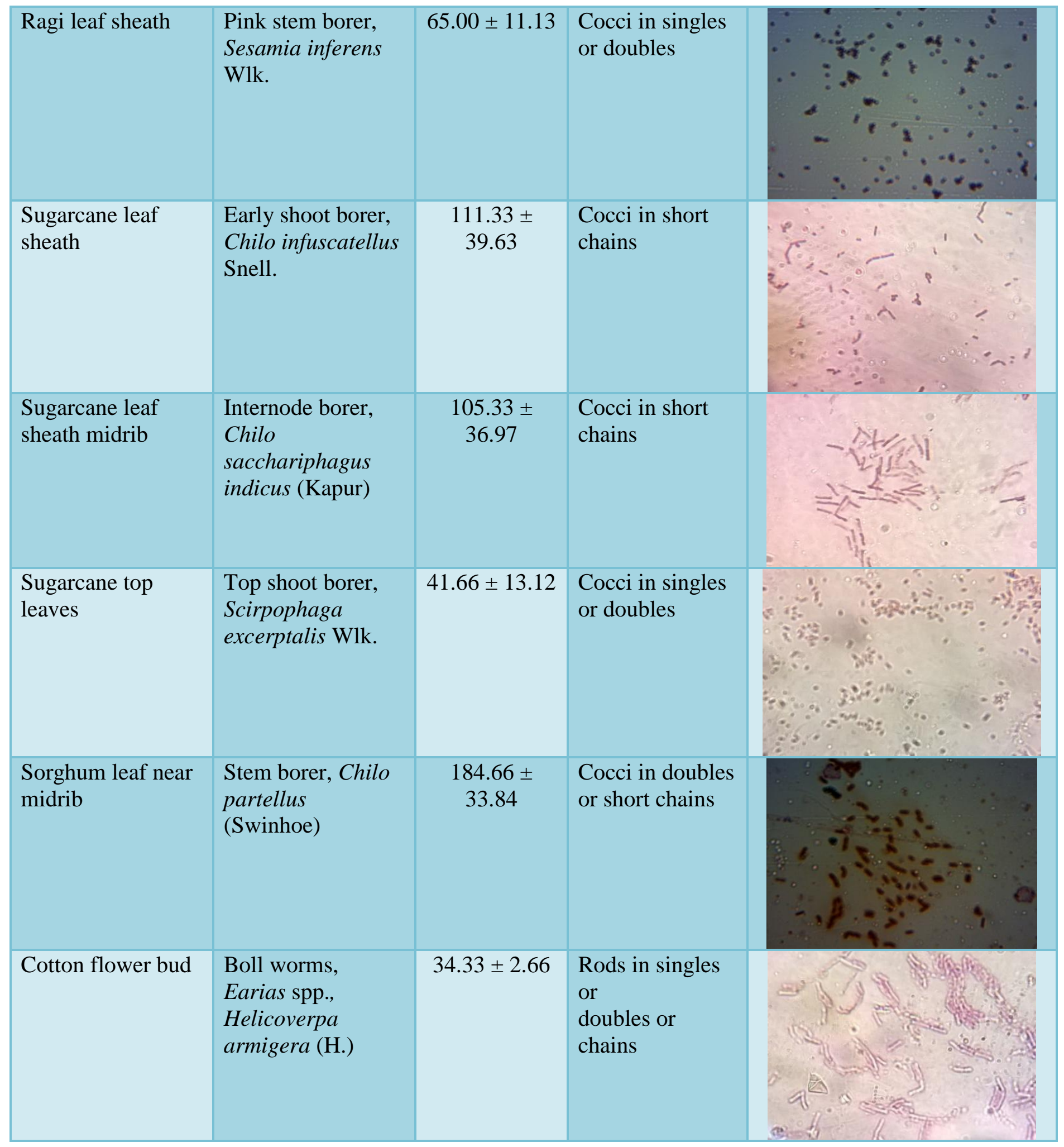




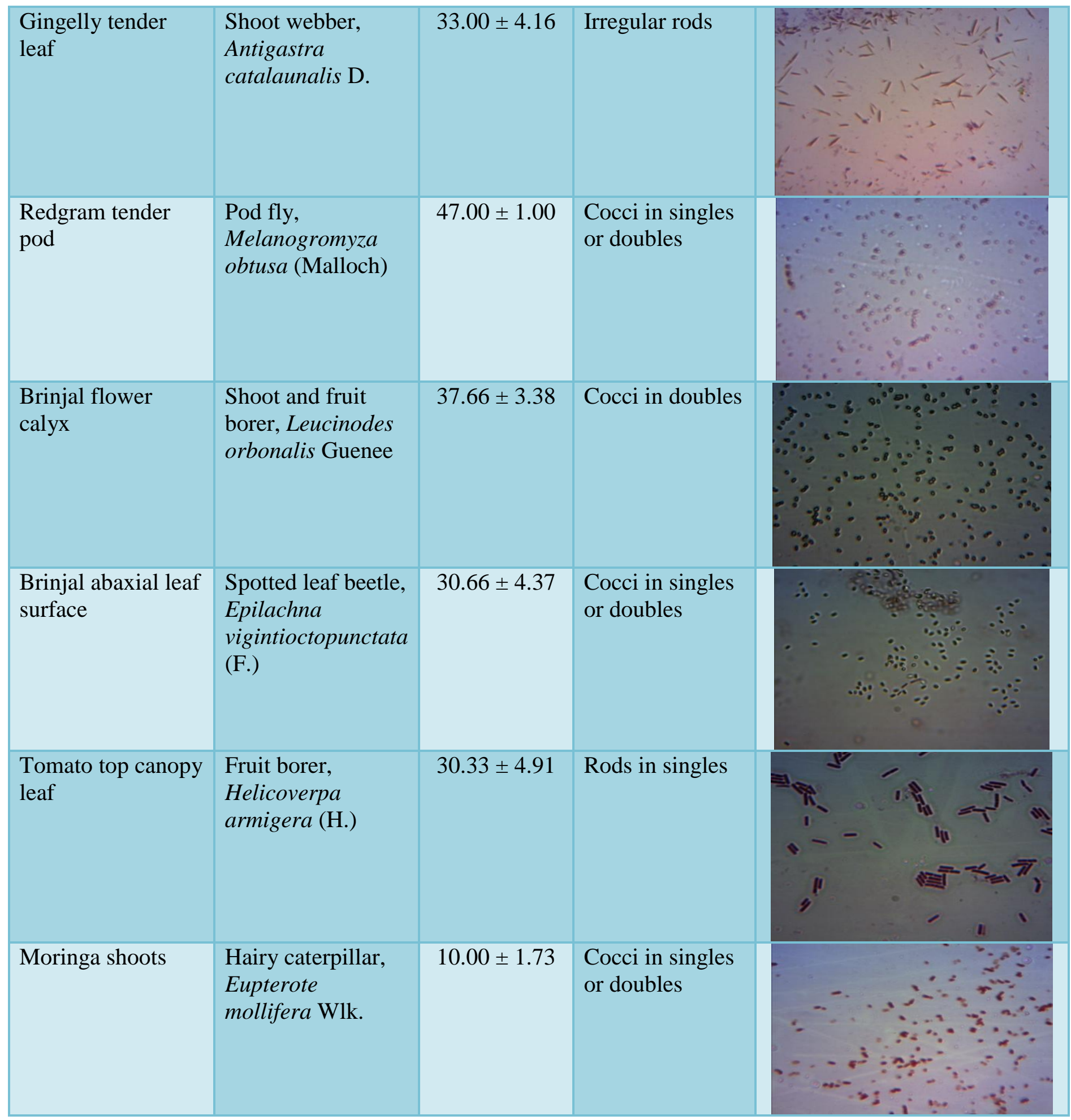




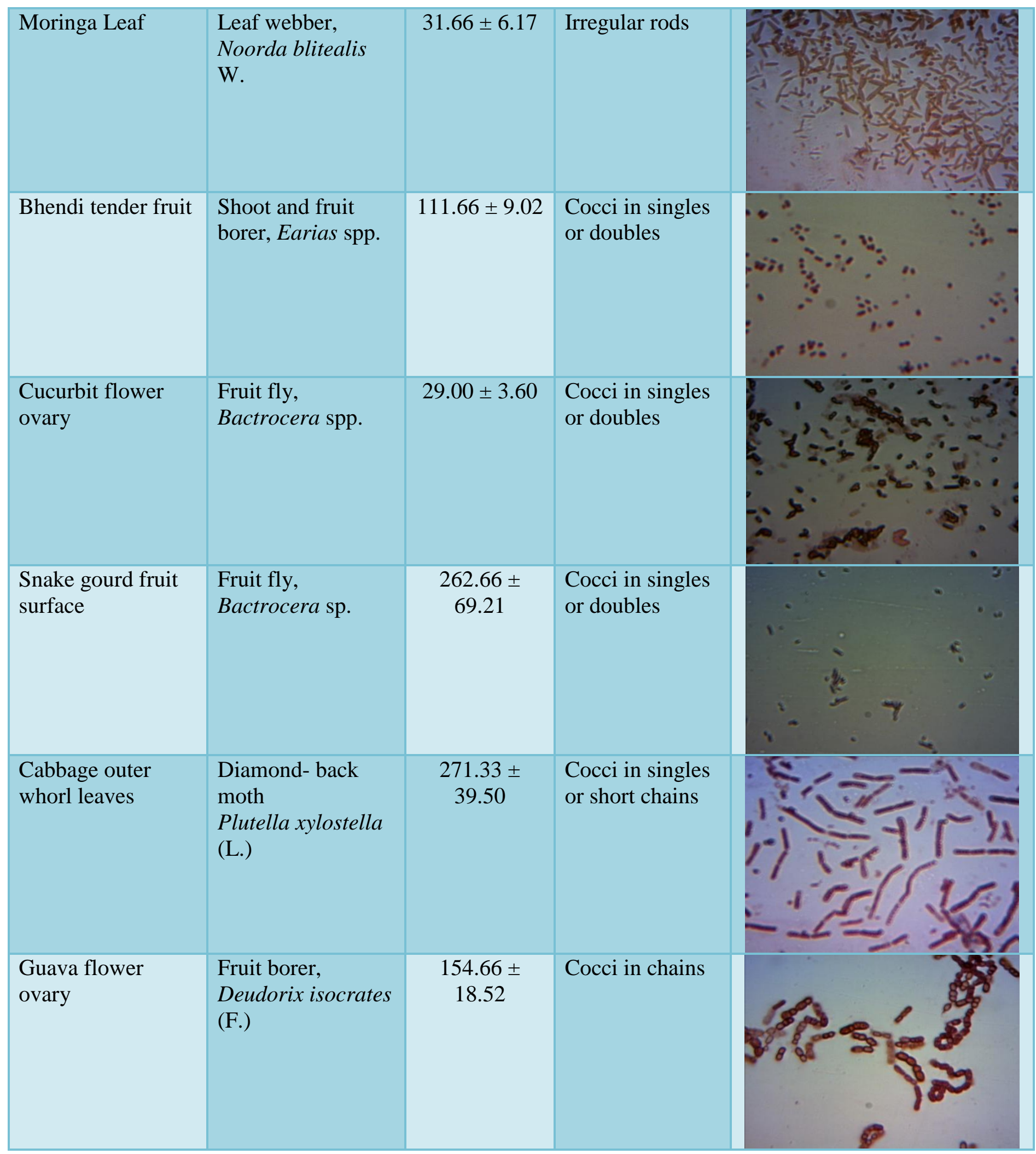




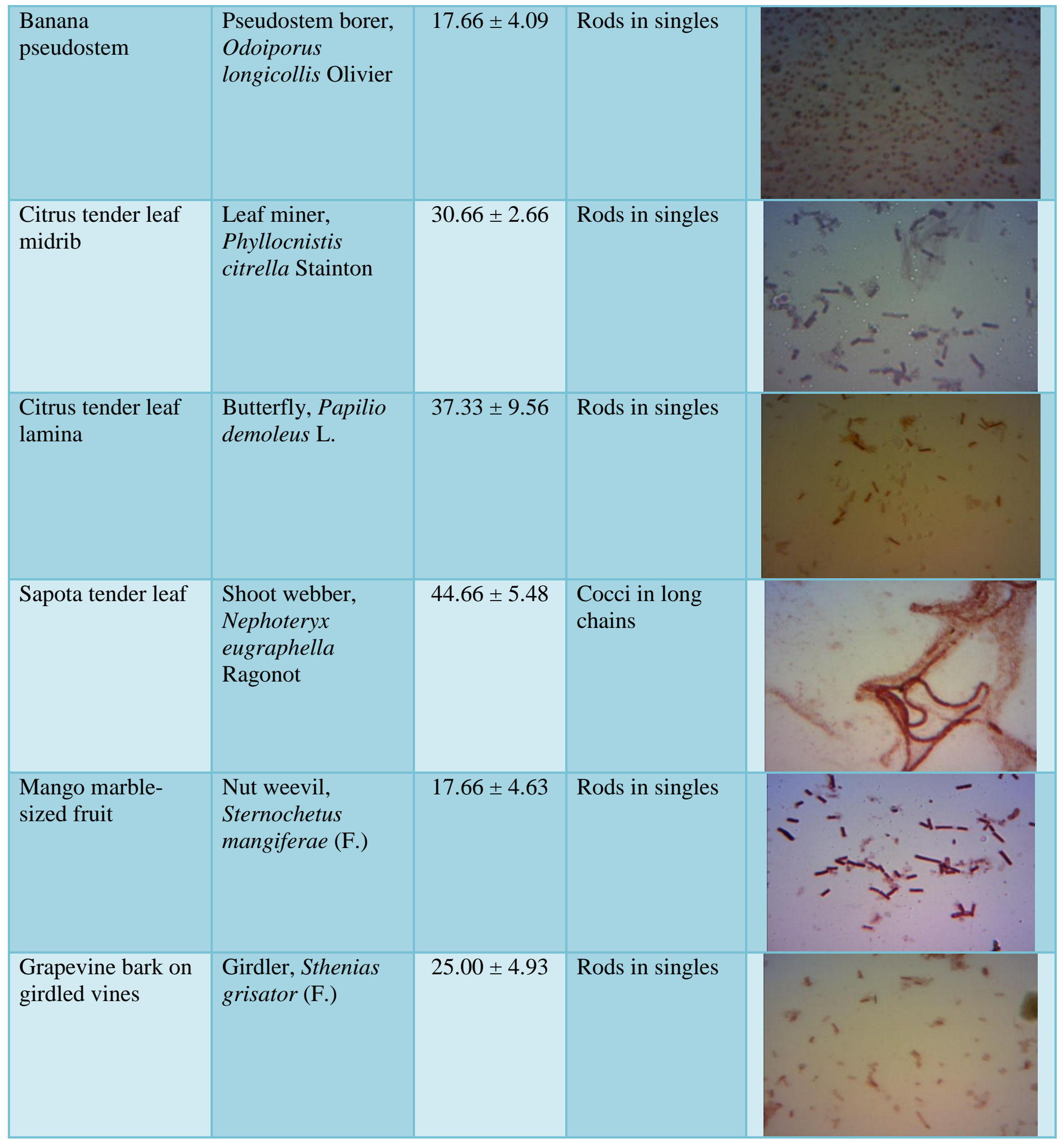




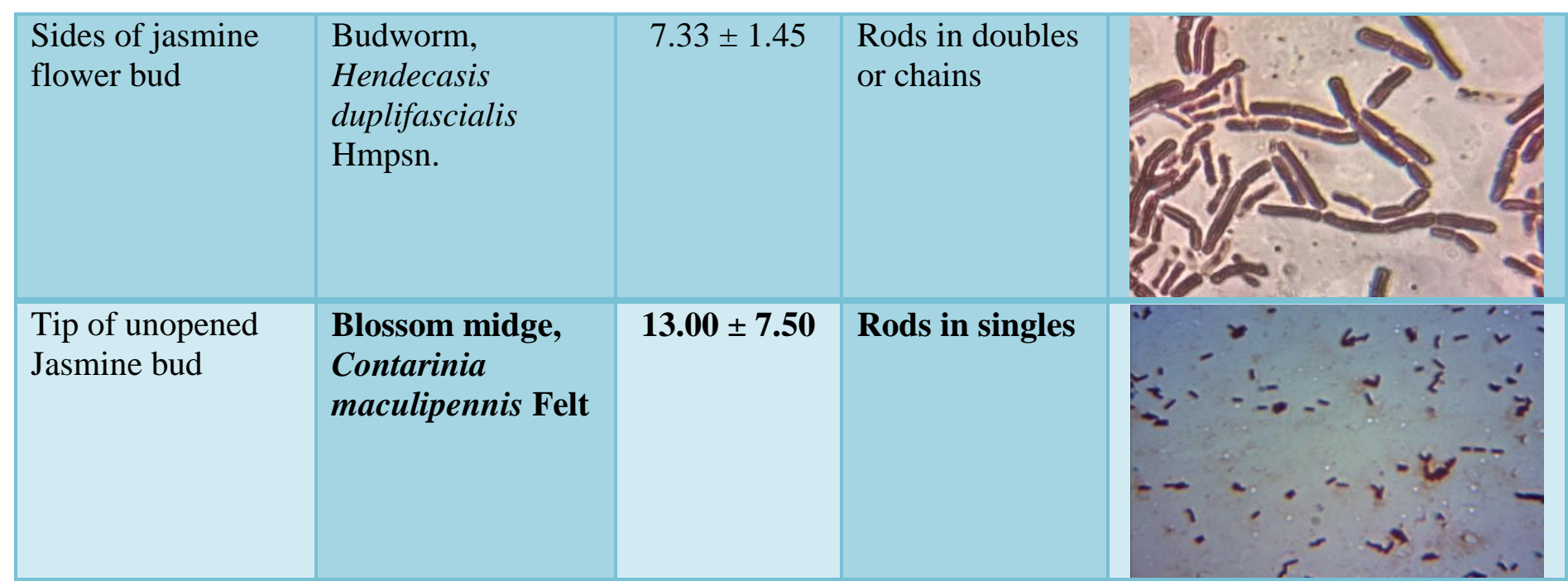

(CFU, colony forming unit; mean of 3 replicates $\pm \mathrm{SE}$ )

Table. 2 Mean LAB population and damage due to pests in rice after spraying LAB culture field experiments

\begin{tabular}{|c|c|c|c|c|}
\hline \multirow[t]{2}{*}{ Treatments } & \multirow{2}{*}{$\begin{array}{c}\text { LAB population } \\
\text { (CFU / leaf } \\
\text { sample) }\end{array}$} & \multirow{2}{*}{$\begin{array}{l}\text { C. medinalis } \\
\text { injury } \\
(\%)\end{array}$} & \multicolumn{2}{|c|}{ \% damage due to $S$. incertulas } \\
\hline & & & Dead hearts & White ear \\
\hline $\begin{array}{l}\text { LAB culture } \\
\text { spray }\end{array}$ & $\begin{array}{l}32.61 \pm 2.52 \\
(1.46 \pm 0.03)\end{array}$ & $\begin{array}{c}13.35 \pm 2.47 \\
(16.92 \pm 2.13)\end{array}$ & $\begin{array}{c}0.91 \pm 0.57 \\
(5.38 \pm 1.03)\end{array}$ & $\begin{array}{c}14.06 \pm 1.80 \\
(20.10 \pm 1.70)\end{array}$ \\
\hline $\begin{array}{l}\text { Untreated } \\
\text { control }\end{array}$ & $\begin{array}{l}42.15 \pm 5.27 \\
(1.52 \pm 0.05)\end{array}$ & $\begin{array}{l}16.73 \pm 2.83 \\
(6.53 \pm 0.81)\end{array}$ & $\begin{array}{c}3.04 \pm 0.81 \\
(7.10 \pm 1.26)\end{array}$ & $\begin{array}{c}16.22 \pm 1.90 \\
(21.75 \pm 1.80)\end{array}$ \\
\hline Observations (n) & 47 & 50 & 35 & 35 \\
\hline$t$ - value & NS & $6.14(P<0.05)$ & $2.13(\mathrm{P}<0.05)$ & NS \\
\hline
\end{tabular}

(CFU, colony forming unit; Figures in parenthesis are transformed values; NS, not significant)

Table.3 Diversity of LAB isolated from healthy and mite infested leaves of Rutaceae showing their morphology and population.

\begin{tabular}{|l|c|l|}
\hline \multicolumn{1}{|c|}{ Leaves } & $\begin{array}{c}\text { LAB population } \\
\text { (CFU/ leaf sample) }\end{array}$ & \multicolumn{1}{c|}{ Cell morphology } \\
\hline Healthy citrus leaf & $33.33 \pm 4.91$ & Rods in singles \\
\hline Mite-infested citrus leaf & $40.33 \pm 8.87$ & Cocci in singles or chains \\
\hline Healthy curry leaf & $9.0 \pm 2.0$ & Cocci in short chains \\
\hline Mite-infested curry leaf & $164.66 \pm 23.1$ & Cocci in singles or short chains \\
\hline
\end{tabular}

(CFU, colony forming unit; mean of 3 replicates \pm SE) 
Figure.1 LAB population $(n=8)$ and dead hearts damage $(n=60)$ in rice following LAB spray and $S$. incertulas egg mass introduction in the screenhouse experiment. CFU, colony forming unit. Columns with the same letter are not significantly different according to paired $t$ test $(\mathrm{P}<$

0.05). Vertical bars indicate the standard error

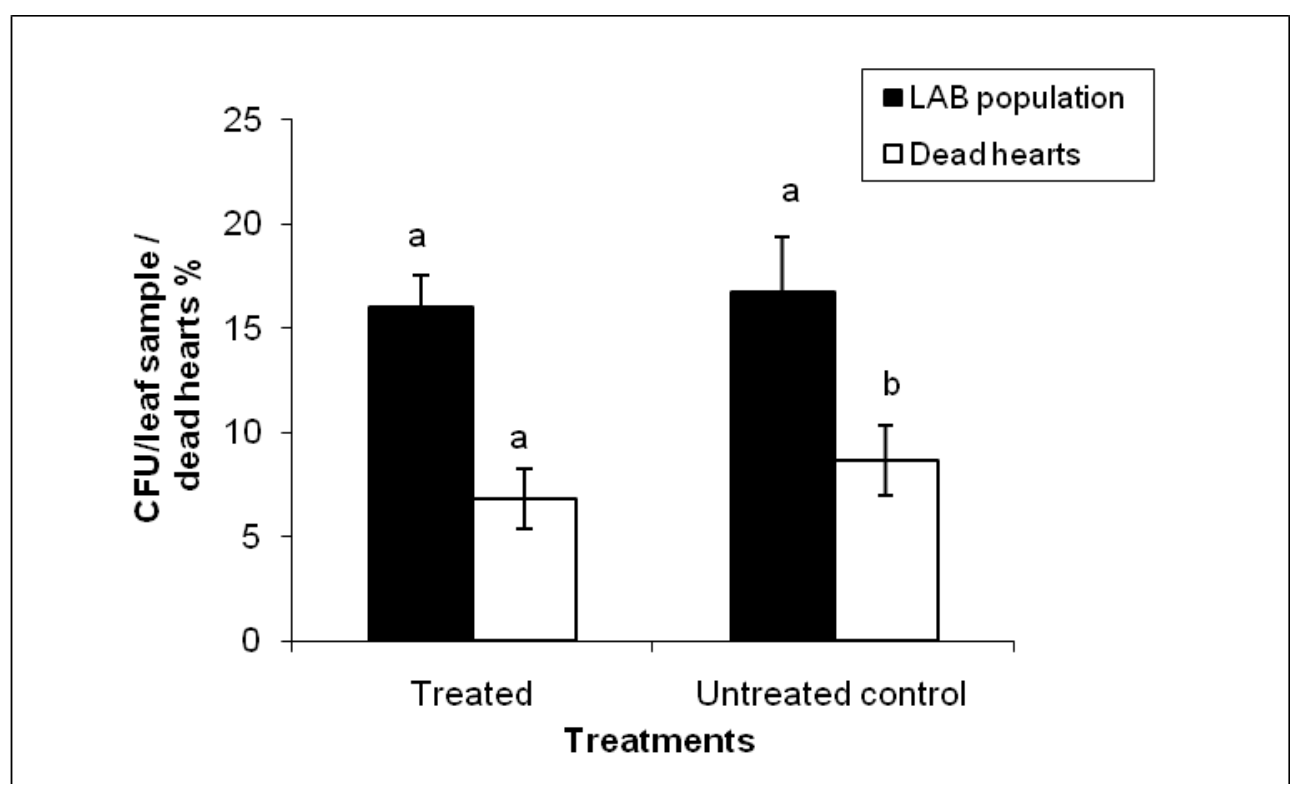

Similarly, the LAB differed morphologically on moringa shoots and on leaves where Eupterote mollifera Wlk. and Noorda blitealis W. lay eggs, respectively. On the other hand, the $\mathrm{LAB}$ on young citrus leaves seem to attract both the leaf miner, Phyllocnistis citrella Stainton and the butterfly Papilio demoleus L. as both the pests select the same site for oviposition. Thus the diversity in the morphology of epiphytic LAB species may be associated with pest susceptibility which needs to be investigated further. Moreover, LAB density may also differ with plant age or part/site. For instance, LAB were more numerous both on mite-infested older citrus and curry leaves $(40.33 \pm 8.87-164.66 \pm$ 23.10 CFU/leaf sample) than on mite-free young citrus and curry leaves $(9.0 \pm 2.0$ $33.33 \pm 4.91 \mathrm{CFU} / \mathrm{leaf}$ sample) (Table 3). Therefore pest populations and their behaviour can be manipulated by LAB strains isolated from different crop sites or age or source.

\section{LAB culture spray and rice pests}

Screenhouse and field experiments also demonstrated the presence of LAB at different crop growth stages in rice. Along with the native LAB, they appeared to have significantly influenced $S$. incertulas both in screenhouse and field, probably repelling adult moths thereby injury to leaves, though not to tillers. In natural farming, LAB-rich rice rinse water is used to protect crops (Ikeda et al., 2013). With no pest infestation noticed in harvested paddy straw, a cattle feed, LAB on paddy straw would probably deter insects as they occur in large populations on them (347.66 $\pm 43.05 \mathrm{CFU} /$ leaf sample) (Table 1). Consequently, cow dung is generally considered as a vehicle for the distribution of LAB onto field-grown crops and vegetables (Henning et al., 2015). It has already been established that the behaviour and biology of brown planthopper, Nilaparvata lugens (Stal) are significantly influenced by rice plant volatiles extracted as steam distillates (Saxena 
and Okech, 1985). It is worth probing the influence of LAB-produced volatiles on BPH too in future as bacterial microbes representing the phyla Proteobacteria, Firmicutes, Actinobacteria and Bacteroidetes are found in N. lugens (Tang et al., 2010). Rice plant LAB may also be associated with its chemical ecology. Thus LAB on oviposition sites of crops are also likely to play a key role in pest management too as they are as diverse as crops or pests. This, in conclusion, opens up a new research area in agricultural entomology hitherto unexplored: could epiphytic LAB influence insect behaviour and abundance?

\section{Acknowledgement}

The support rendered by Dr. P. Pandiyarajan, Dean, Anbil Dharmalingam Agricultural College and Research Institute, Trichy is gratefully acknowledged.

\section{References}

Stiles, M.E. and Holzapfel, W.H., 1997. Lactic acid bacteria of foods and their current taxonomy. International Journal of Food Microbiology 36, 129.

Makarova, K., Slesarev, A., Wolf, Y., Sorokin, A., Mirkin, B., Koonin, E., Pavlov, A., Pavlova, N., Karamychev, V., Polouchine, N. and Shakhova, V., 2006. Comparative genomics of the lactic acid bacteria. Proceedings of National Academy of Science 103, 15611-15616.

Vásquez, A., Forsgren, E., Fries, I., Paxton, R.J., Flaberg, E., Szekely, L. and Olofsson, T.C., 2012. Symbionts as major modulators of insect health: lactic acid bacteria and honeybees. PLoS One 7, e33188.

Mathialagan, M., 2014. Probiotic lactic acid bacteria (LAB) for Varroa-associated stress management in honeybees. $\mathrm{M}$.

Sc. (Ag.) Thesis, Agricultural Entomology Department, Tamil Nadu Agricultural University, Tamil Nadu, India.

Salminen, S., Von Wright, A., Morelli, L., Marteau, P., Brassart, D., de Vos, W.M., Fonden, R., Saxelin, M., Collins, K., Mogensen, G. and Birkeland, S.E., 1998. Demonstration of safety of probiotics - a review. International Journal of Food Microbiology, 44, 93-106.

Carr, F.J., Chill, D. and Maida, N., 2002. The lactic acid bacteria: a literature survey. Critical Reviews of Microbiology 28, 281-370.

Dalie, D.K.D., Deschamps, A.M. and Richard-Forget, F., 2010. Lactic acid bacteria - potential for control of mould growth and mycotoxins: a review. Food Control 21, 370-380.

Harzallah, D. and Belhadj, H., 2013. Lactic acid bacteria as probiotics: characteristics, selection criteria and role in immunomodulation of human gi muccosal barrier. Kongo M, 197216.

Trias, R., Baneras, L., Segui, E.M. and Romanyo, E.B., 2008. Lactic acid bacteria from fresh fruit and vegetables as biocontrol agents of phytopathogenic bacteria and fungi. International Journal of Microbiology 11, 231-236.

Zheng, L., Crippen, T.L., Holmes, L., Singh, B., Pimsler, M.L., Benbow, M.E., Tarone, A.M., Dowd, S., Yu, Z., Vanlaerhoven, S.L., Wood T.K. and Tomberlin, J.K., 2013. Bacteria mediate oviposition by the black soldier fly, Hermetia illucens (L.), (Diptera: Stratiomyidae). Scientific Reports 3: 2563.

Wright, C.T. and Klaenhammer, T.R., 1981. Calcium-induced alteration of cellular 
affecting the resistance of Lactobacillus acidophilus to freezing. Applied and Environmental Microbiology 41, 807-815.

Aween, M.M., Hassan, Z., Muhialdin, B.J., Noor, H.M. and Eljamel, Y.A., 2012. Evaluation on antibacterial activity of Lactobacillus Acidophilus strains isolated from honey. American Journal of Applied Sciences 9, 807817.

Mostafiz, S.B., Rahman, M. and Rahman, M., 2012. Biotechnology: role of microbes in sustainable agriculture and environmental health. International Journal of Microbiology 10, 1-6.

Murthy, K.N., Malini, M., Savitha, J. and Srinivas, C., 2012. Lactic acid bacteria (LAB) as plant growth promoting bacteria (PGPB) for the control of wilt of tomato caused by Ralstonia solanacearum. Pest Management in Horticultural Ecosystem 18, 60-65.

Higa, T. and Kinjo, S., 1991. Effect of lactic acid fermentation bacteria on plant growth and soil humus formation. In: Proceedings of the 1st International Conference on Kyusei Nature Farming, October 17-21, 1989, Parr, J.F., S.B. Hornick and C.E. Whitman (Eds.). Khon Kaen University, Khon Kaen, Thailand, pp: 140.

Kannan, N.M., Abhiramy and Rajvanshi, P., 2014. Efficacy of a probiotic Lactobacillus as a biocontrol agent and plant growth promoting bacteria by controlling Xanthomonas campestris infection in chilli plant. International Journal of advances in Pharmacy. Biology and Chemistry 3, $1016-1027$.

Okumu, F.O., Killeen, G.F., Ogoma, S., Biswaro, L., Smallegange, R.C., Mbeyela, E., Titus, E., Munk, C., Ngonyani, H., Takken, W. and
Mshinda, H., 2010. Development and field evaluation of a synthetic mosquito lure that is more attractive than humans. PloS One 5, e8951.

James, A.G., Hyliands, D. and Johnston, H., 2004. Generation of volatile fatty acids by axillary bacteria. International Journal of Cosmetic Science 26, 149-156.

Smallegange, R.C., Qiu, Y.T., Bukovinszkine-Kiss, G., Van Loon, J.J. and Takken, W., 2009. The effect of aliphatic carboxylic acids on olfaction-based host-seeking of the malaria mosquito Anopheles gambiae sensu strict. Chemical Senses 30, 145152.

Knols, B.G., Van Loon, J.J., Cork, A., Robinson, R.D., Adam, W., Meijerink, J., De Jong, R. and Takken, W., 1997. Behavioural and electrophysiological responses of the female malaria mosquito Anopheles gambiae (Diptera: Culicidae) to limburger cheese volatiles. Bulletin of Entomological Research 87, 151-159.

Choi, J., Yoon, K.H., Kalichamy, S.S., Yoon, S.S. and Lee, J.I., 2016. A natural odor attraction between lactic acid bacteria and the nematode Caenorhabditis elegans. Multidisciplinary Journal of Microbial Ecology 10, 558-567.

Doi, K., Phuong, O. T. A., Kawatou, F., Nagayoshi, Y., Fujino, Y. and Ohshima, T., 2013. Identification and characterization of lactic acid bacteria isolated from fermented rice bran product. Advances in Microbiology 3, 265-272.

Olympia, M., Fukuda, H., Ono, H., Kaneko, Y. and Takano, M., 1995. Characterization of starch-hydrolyzing lactic acid bacteria isolated from a fermented fish and rice food,"Burong Isda", and its amylolytic enzyme. 
Journal of Fermentation and Bioengineering 80, 124-130.

Fukushima, K., Sogo, K., Miura, S. and Kimura, Y., 2004. Production of Dlactic acid by bacterial fermentation of rice starch. Macromolecular Biosciences 4, 1021-1027.

Sobrun, Y., Bhaw-Luximon, A., Jhurry, D. and Puchooa, D. 2012. Isolation of lactic acid bacteria from sugar cane juice and production of lactic acid from selected improved strains. Advances in Biosciences and Biotechnology 3, 398-407.

Aplevicz, K.S., Mazo, J.Z., Ilha, E.C., Dinon, A.Z. and Anna, E.S.S., 2014. Isolation and characterization of lactic acid bacteria and yeasts from the Brazilian grape sourdough. Brazilian Journal of Pharmaceutical Sciences 50, 321-332.

Gao, L., Yang, H., Wang, X., Huang, Z., Ishii, M., Igarashi, Y. and Cui, Z., 2008. Rice straw fermentation using lactic acid bacteria. Bioresource Technology 99, 2742-2748.

Ni, K., Wang, Y., Li, D., Cai, Y. and Pang, H., 2015. Characterization, identification and application of lactic acid bacteria isolated from forage paddy rice silage. PloS One 10, e0121967.

Jolly, L., Vincent, S.J., Duboc, P. and Neeser, J.R., $\quad 2002 . \quad$ Exploiting exopolysaccharides from lactic acid bacteria. Antonie van Leeuwenhoek 82, 367-374.

Sanchez, J.I., Martínez, B., Guillen, R., Jimenez-Diaz, R. and Rodriguez, A., 2006. Culture conditions determine the balance between two different exopolysaccharides produced by Lactobacillus pentosus LPS26. Applied Journal of Environmental Microbiology 72, 7495-7502.

Boels, I.C., Ramos, A., Kleerebezem, M. and de Vos, W.M. 2001. Functional analysis of the Lactococcus lactis galU and galE genes and their Impact on sugar nucleotide and exopolysaccharide biosynthesis. Applied Journal of Environmental Microbiology 67, 3033-3040.

De Vuyst, L. and Degeest, B., 1999. Heteropolysaccharides from lactic acid bacteria. FEMS Microbiology Reviews 23, 153-177.

Vandenbergh, P.A., 1993. Lactic acid bacteria, their metabolic products and interference with microbial growth. FEMS Microbiology Reviews 12, 221-237.

Rattanachaikunsopon, P. and Phumkhachorn, P., 2010. Lactic acid bacteria: their antimicrobial compounds and their uses in food production. Annals of Biological Research 1, 218- 228.

Piard, J.C. and Desmazeaud, M., 1991. Inhibiting factors produced by lactic acid bacteria oxygen metabolites and catabolism end-products. Le lait 71, 525-541.

Tagg, J.R., Dajani, A.S. and Wannamaker, L.W., 1976. Bacteriocins of grampositive bacteria. Bacteriological Reviews 40, 722.

Lindgren, S.E. and Dobrogosz, W.J., 1990. Antagonistic activities of lactic acid bacteria in food and feed fermentations. FEMS Microbiological Letters 7, 149-163.

Alagukannan, G. and Ashokkumar, M., 2015. Role of effective microorganisms (EM) in sustainable agriculture - A review and recommendations. International Journal of Scientific Research 4, 577-578.

Renwick, J.A.A., 1989. Chemical ecology of oviposition in phytophagous insects. Experientia 45, 223-228.

Lam, K., Babor, D., Duthie, B., Babor, E.M., Moore, M. and Gries, G., 2007. Proliferating bacterial symbionts on 
house fly eggs affect oviposition behaviour of adult flies. Animal Behaviour 74, 81-92.

Henning, C., Vijayakumar, P., Adhikari, R., Jagannathan, B., Gautam, D. and Muriana, P.M., 2015. Isolation and taxonomic identity of bacteriocinproducing lactic acid bacteria from retail foods and animal sources. Microorganisms 3, 80-93.

Ikeda, D.M., Weinert, J.E., Chang, K.C., Mc Ginn, J.M., Miller, S.A., Keliihoomalu, C. and DuPonte, M.W., 2013. Natural farming: lactic acid bacteria. Journal of Sustainable
Agriculture 8, 1-4.

Saxena, R.C. and Okech, S.H., 1985. Role of plant volatiles in resistance of selected rice varieties to brown planthopper, Nilaparvata lugens (Stal) (Homoptera: Delphacidae). Journal of Chemical Ecology 11, 1601-1616.

Tang, M., Lv, L., Jing, S., Zhu, L. and He, G., 2010. Bacterial symbionts of the brown planthopper, Nilaparvata lugens (Homoptera: Delphacidae). Applied Journal of Environmental Microbiology 76, 1740-1745.

\section{How to cite this article:}

Harshini, R., P. Yasodha, K.G. Sabarinathan, V. Ambethgar and David, P.M.M. 2018. Diversity of Epiphytic Lactic Acid Bacteria (LAB) on Insect Oviposition Sites. Int.J.Curr.Microbiol.App.Sci. 7(07): 607-621. doi: https://doi.org/10.20546/ijcmas.2018.707.074 